\title{
POTENTIAL PATHOGENICITY OF PASTURE PLANT ROOT-COLONISING FUNGI TO SEEDLINGS OF LEGUMES AND GRASSES
}

\author{
N.W.WAIPARA ${ }^{1,3}$, M.E. DI MENNA ${ }^{1}$, A.L.J. COLE ${ }^{3}$ and R.A. SKIPP ${ }^{2}$ \\ ${ }^{1}$ New Zealand Pastoral Agriculture Research Institute, \\ Private Bag 3123, Hamilton, and \\ ${ }^{2}$ Private Bag 11008, Palmerston North \\ ${ }^{3}$ University of Canterbury, Private Bag 4800, Christchurch
}

\begin{abstract}
A rapid screening test using seedlings grown axenically on water agar was used to determine the capacity of 70 fungal species, isolated from pasture plant roots, to invade and damage seedling roots of 12 plant species common in Waikato pastures. Deleterious effects on roots of one or more plant species occurred following inoculation with these fungi and some species showed potential to be virulent pathogens, particularly to clover seedlings which were more susceptible to root damage by a larger number of fungi than grass seedlings. The technique proved to be a useful preliminary screen to select fungal species and isolates for more detailed studies on their importance in reducing plant emergence and persistence in pasture.
\end{abstract}

Keywords: Pathogenicity, root-colonising fungi, pasture, seedlings

\section{INTRODUCTION}

A qualitative and quantitative survey of root-colonising fungi associated with the roots of dairy and and hill country pasture plants in the Waikato, obtained over 7000 fungal isolates from surface sterilised root segments (Waipara unpublished). One objective of the study was to investigate the potential of soil and rhizosphere fungi as pathogens of pasture plants and seedlings. Previous investigations have identified an array of root-colonising fungi which can be significant pathogens of ryegrass (Falloon 1985; Skipp and Christensen 1989), white clover (Skipp and Christensen 1982) and red clover (Nan et al. 1991).

To enable selection of pathogenic species of root-colonising fungi for further investigation in pot and field trials, a rapid preliminary test (Christensen et al. 1988) was used to determine the capacity of 70 species of fungi isolated from roots of pasture plants in the Waikato to invade and damage seedlings of legumes and grasses.

\section{MATERIALS AND METHODS}

Seventy fungi species (Table 1) isolated from pasture roots were screened against the following 12 pasture species; 'Grasslands Huia' white clover (Trifolium repens L.), 'Grasslands Pawera' red clover (Trifolium pratense L.), 'Grasslands Maku' lotus (Lotus uliginosus Schkuhr), 'Grasslands Wana' cocksfoot (Dactylis glomerata L.), 'Grasslands AK 1003' subterranean clover (Trifolium subterraneum L.), 'Grasslands Kahu' timothy (Phleum pratense L.), 'Massey Basyn' yorkshire fog (Holcus lanatus L.), 'WT Whatawhata' goosegrass (Bromus mollisL.), 'Grasslands Egmont' browntop (Agrostis capillaris L.), 'Grasslands BZ 2330'sweet vernal (Anthoxanthum odoratum L.), 'Grasslands Roa' tall fescue (Festuca arundinacea L.) and endophyte-free 'Grasslands Nui' perennial ryegrass (Lolium perenne L.). All fungal isolates are part of the Canterbury University microbial culture collection and are stored in $10 \%$ glycerol at $-80^{\circ} \mathrm{C}$.

Seeds were surface sterilised in $1 \%$ sodium hypochlorite solution for 5 min followed by three rinses in sterile water. Sweet vernal and goosegrass seeds were also 
soaked in $50 \%$ sulphuric acid for $15 \mathrm{~min}$ as a preliminary treatment as both had rough hairy seedcoats. Surface sterilised seeds were placed in a row onto $1.5 \%$ water agar petri plates. Plates were placed on edge in a $20^{\circ} \mathrm{C}$ incubator with seeds aligned so that roots grew parallel to each other and across the agar surface. Following germination of the seeds, each plate was inoculated with a $3 \mathrm{~mm}$ culture plug of the test fungus which had been grown for 7 days on potato carrot agar. One isolate of each fungus was inoculated onto six seedlings of each host. Inoculated plates were returned to the incubator for 5 days followed by a further 5 days incubation in daylight at room temperature. Control plates remained uninoculated. Plates were examined after 10 days and scored according to symptoms exhibited. A disease score 0-5 was assigned to each seedling based on observable disease symptoms, as follows: $0=$ White turgid roots with no visible symptoms (non pathogenic); $1=$ Light browning or discoloration of root tissue (non pathogenic); 2 = Darker discoloration (browning) of root tissue (weakly pathogenic); $3=$ Root surface lesions present and/or inhibition of root growth (mildly pathogenic); $4=$ Systemic root lesioning and necrosis (pathogenic); $5=$ Complete seedling death (pathogenic).

A pathogenicity rating was calculated for each isolate on each host by averaging the six disease scores from plates for each treatment.

\section{RESULTS AND DISCUSSION}

This in vitro petri plate technique was successful in quickly demonstrating which species of fungi were pathogenic to a range of pasture grasses and legumes. Within 10 days, disease symptoms had appeared on susceptible host seedlings, and these allowed a pathogenicity rating to be calculated. Leguminous seedlings were susceptible to disease symptoms from a larger number of fungi than grass seedlings (Fig. 1). Red clover was the most susceptible host with 33 species of fungi causing disease, while goosegrass and tall fescue were susceptible to only nine and seven species respectively. Lotus was the least susceptible legume showing susceptibility to 18 species which was less than the most susceptible grasses (perennial ryegrass, yorkshire fog and cocksfoot). Declining productivity and poor persistence of forage legumes in pastures has been widely reported (Leath 1989) and these results further demonstrate that there are many species of root-invading fungi with potential for pathogenicity to pasture plants.

Of the 70 species of fungi inoculated onto seedlings (Table 1), nine species of Fusarium showed a broad host range and gave high disease scores of 4-5. As fusaria are

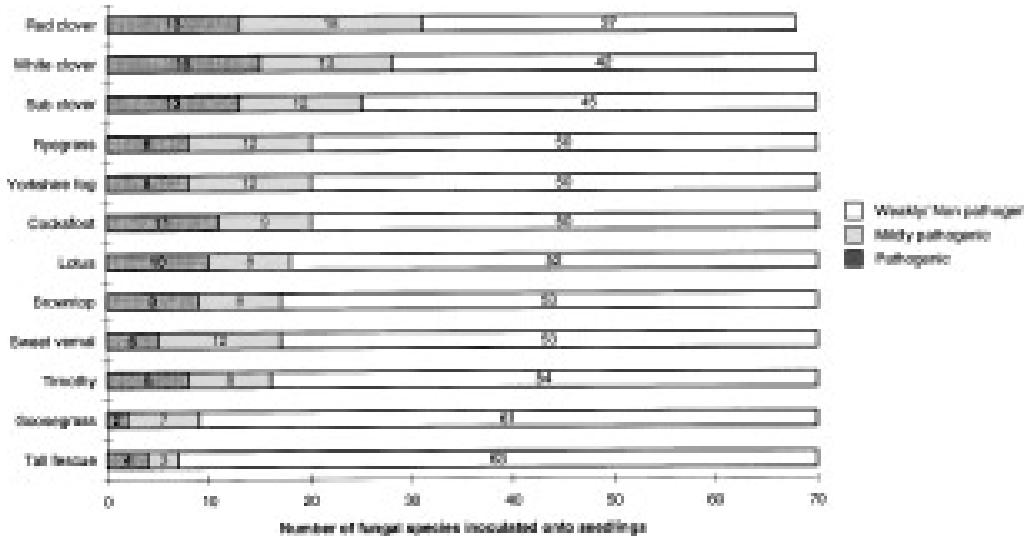

FIGURE 1: Number of fungi classed as pathogenic, weakly pathogenic or non pathogenic to seedlings of pasture legumes and grasses as determined using a petri plate technique. 
ubiquitous soil and root-colonising fungi, they could have a significant impact on seedling establishment in Waikato pastures. Other pathogenic species with broad host ranges were Cylindrocladium scoparium, Rhizoctonia solani, Botrytis cinerea and Phymatotrichum omnivorum(Table 1). The higher susceptibility of leguminous seedlings is further demonstrated with isolates of Cylindrocarpon destructans, Myrothecium verrucaria and Plectosphaerella cucumerina being classed as pathogenic to legumes but only classed as weakly or non pathogenic to grasses. Preussia aemulanswas a hostspecific pathogen, as it was only pathogenic to red clover and non pathogenic to all of the other hosts tested (Table 1). Despite the higher susceptibility of clover seedlings, grass seedlings were also susceptible to root damage by many fungi. The majority of fungal species were, however, weakly or non-pathogenic to most hosts (Fig. 1).

\section{TABLE 1: Species of fungi classed as pathogenic ${ }^{1}$ to pasture legume and grass seedlings using a petri plate technique.}

Fungal species ${ }^{3} \quad$ Pasture Plant $^{2}$

\begin{tabular}{|c|c|c|c|c|c|c|c|c|c|c|c|c|}
\hline & $\mathrm{RC}$ & WC & $\mathrm{SC}$ & RG & YF & $\mathrm{CF}$ & LO & SV & $\mathrm{BT}$ & $\mathrm{TI}$ & GG & TF \\
\hline Acremnoium strictum & 3 & 3 & 3 & - & 1 & 3 & - & 2 & 2 & 2 & - & 1 \\
\hline Botrytis cinerea & 3 & 3 & 2 & 3 & 3 & 3 & 2 & 2 & 3 & 2 & 1 & 1 \\
\hline Clasterosporium & 3 & 3 & 2 & 3 & - & 3 & - & 1 & 1 & - & - & 1 \\
\hline Codinaea fertilis & 2 & 2 & - & 1 & 1 & - & 1 & 1 & 2 & 3 & - & - \\
\hline Colletotrichum & 3 & 3 & 2 & 1 & 1 & 1 & 2 & - & 2 & - & - & - \\
\hline Cylindrocarpon destructans & 3 & 3 & 3 & 3 & 1 & - & - & - & - & - & - & - \\
\hline Cylindrocladium scoparium & 3 & 3 & 3 & 3 & 3 & 3 & 3 & 2 & 3 & 2 & 2 & 2 \\
\hline Dreschlera dematioidea & 2 & 2 & 2 & 2 & 2 & 2 & 1 & 1 & 2 & 2 & 2 & 1 \\
\hline Fusarium acuminatum & 3 & 3 & 3 & 3 & 3 & 3 & 3 & 2 & 3 & 3 & 3 & 3 \\
\hline F. avenaceum & 3 & 3 & 3 & 3 & 3 & 3 & 3 & 3 & 3 & 3 & 3 & 3 \\
\hline F. crookwellense & 3 & 3 & 3 & 3 & 3 & 3 & 3 & 3 & 3 & 3 & 2 & 3 \\
\hline F. culmorum & 3 & 3 & 3 & 3 & 3 & 3 & 3 & 2 & 3 & 3 & 1 & 3 \\
\hline F. equiseti & 3 & 3 & 3 & 1 & 2 & 2 & 2 & 2 & 1 & 1 & 2 & 1 \\
\hline F. oxysporum & 3 & 3 & 3 & 1 & 3 & 3 & 3 & 2 & 3 & 3 & - & - \\
\hline F. sambucinum & 1 & 3 & 3 & 3 & 3 & 2 & 3 & 1 & 2 & 2 & 2 & 1 \\
\hline F. solani & 2 & 3 & 3 & 2 & 2 & 2 & 3 & 1 & 1 & 1 & - & 1 \\
\hline F. tricinctum & 3 & 3 & 3 & 3 & 3 & 3 & 3 & 3 & 3 & 3 & 1 & 3 \\
\hline Gliocladium roseum & 2 & 2 & 3 & 1 & 3 & 2 & 2 & 2 & 1 & 1 & 1 & 1 \\
\hline Microdochium bolleyi & 2 & 3 & 3 & 3 & 2 & 2 & 2 & 3 & 1 & - & - & - \\
\hline Mortierella gamsii & 3 & 3 & 3 & 1 & 1 & - & 2 & 1 & 1 & 1 & 2 & - \\
\hline Myrothecium verrucaria & 3 & 3 & 3 & 2 & 2 & 2 & 1 & 1 & 1 & 2 & - & 1 \\
\hline Phymatotrichum omnivorum & $n 3$ & 3 & 1 & 2 & 2 & 2 & 1 & 2 & 3 & 2 & - & 1 \\
\hline Plectosphaerella cucmerina & 3 & 3 & 3 & 2 & 2 & 1 & 2 & 2 & 1 & - & - & - \\
\hline Preussia aemulans & 3 & - & - & - & - & - & - & - & - & - & - & - \\
\hline Rhizoctonia solani & 3 & 3 & 2 & 2 & 3 & 3 & 3 & 3 & 3 & 3 & - & 2 \\
\hline
\end{tabular}

1 3: pathogenic (average disease scores 4-5), 2: moderately pathogenic (average disease scores 3 -3.9), 1: weakly pathogenic (average disease scores 2-2.9)

${ }^{2}$ RC red clover; WC white clover; SC subterranean clover; RG ryegrass; YF yorkshire fog; CF cocksfoot; LO lotus; SV sweet vernal; BT browntop; TI timothy; GG goosegrass; TF tall fescue.

3 All species tested from the following fungi were classed as non pathogenic to all tested


Chaetomium 2 spp, Curvularia, Dactylaria, Fusarium graminum, Gongronella, Mariannaea, Metarhizium, Mortierella alpina, M. elongata, M. globulifera, Paecilomyces $^{3 \text { spp. }}$, Penicillium ${ }^{\text {spp. }}$, Periconia, Ramichloridium, Sordaria, Tetraploa, Thielaviopsis, Thozetella, Tricellula, Trichoderma ${ }^{6 \mathrm{spp}}$, Trichosporon, Verticillium and Verticicladiella. 
This in vitro test provides a preliminary indication of potential root colonisation, host specificity and pathogenicity of fungi to host seedlings. However, the test may not be indicative of that under field conditions which are influenced by other microbial interactions in the rhizosphere.

\section{CONCLUSIONS}

This petri plate technique provided a quick method to assess potential pathogenicity of a large number of fungi across a wide host range. Virulent pathogens of pasture seedlings were identified within 10 days or less. Species of Fusarium, Cylindrocladium, Rhizoctonia and Botrytis were particularly pathogenic to all hosts. Clover seedlings were more susceptible to conspicuous damage by these fungal species than grass seedlings. The results of this screen demonstrate the pathogenic potential of some of these root-colonising fungi which could affect the establishment and persistence of seedlings in Waikato pastures, and have provided information on fungal species that warrant further investigation as production limiting pathogens of pasture plants.

\section{REFERENCES}

Christensen, M.J., Falloon R.E. and Skipp, R.A., 1988. A petri plate technique for testing pathogenicity of fungi to seedlings and inducing fungal sporulation. Austral. Plant Path. 17: 45-47.

Falloon, R.E., 1985. Fungi pathogenic to ryegrass seedlings. Plant and Soil 86: 79-86. Leath, K. T., 1989. Diseases and forage stand persistence in the United States. Pp. 465478 In: Persistence of Forage Legumes, G.C. Marten, A.G. Matches, R.F. Barnes, R.W. Brougham, R.J. Clements and G.W. Sheath (Eds); Madison, Wisconsin.

Nan, Z.B., Long, P.G. and Skipp, R. A., 1991. Effect of several root pathogenic fungi on growth of red clover under field conditions. N.Z. J. Agric. Res. 34: 263-269.

Skipp, R.A. and Christensen, M.J., 1989. Fungi invading roots of perennial ryegrass (Lolium perenne L.) in pasture. N.Z. J. Agric. Res. 32: 423-431.

Skipp, R.A. and Christensen, M.J., 1982. Invasion of white clover roots by fungi and other soil microorganisms. III The capacity of fungi isolated from white clover roots to invade seedling root tissue. N.Z. J. Agric. Res. 25: 97-101. 